\title{
マイクロダイアリシス法を用いた溶出試験の改良
}

\author{
長 井 紀 章, 村尾 卓 俊, 伊 藤 吉 將*
}

\section{Improvement of Dissolution Test Using Microdialysis Method}

\author{
Noriaki NaGaI, Takatoshi MuraO, and Yoshimasa ITO* \\ School of Pharmacy, Kinki University, 3-4-1 Kowakae, Higashi-Osaka 577-8502, Japan
}

(Received May 8, 2009; Accepted September 8, 2009)

\begin{abstract}
Dissolution testing is a core performance test in pharmaceutical development and quality control. Generally, the HPLC method uses the analysis of dissolution testing. In this study, we attempted to improve the dissolution test by using microdialysis methods. We also investigated the comparison of the conventional HPLC dissolution method (batchsampling method) and the improved dissolution test (microdialysis method). Histamine $\mathrm{H}_{2}$-receptor antagonist cimetidine tablets $(200 \mathrm{mg})$, which are used clinically and of which there are also some generic examples, were selected for this comparison, and the dissolution behavior of the tablets by the two methods were found to be similar. On the other hand, standard deviation in the microdialysis method was lower than that of the batch-sampling method. In addition, the microdialysis method can omit many steps such as the filtration, collection and replenishment of sample solutions, and is also able to accomplish continuous sampling of sample solutions. These findings provide significant information that can be used in the pharmaceutical development and quality control of original and generic products.
\end{abstract}

Key words_— dissolution test; microdialysis; quality control; cimetidine; generic product

緒言

現在，日本は急速な高齢化に伴い，欧米先進国と は比較にならない早さで高齢化社会を迎え，国民医 療費の増加が問題となっている。これら国民医療費 は 2006 年には 33.1 兆円を超え，社会保障制度の根 幹を摇るがすほどの情勢となり，国民医療費の抑制 は大きな課題となっている。この国民医療費の抑制 における取り組みの 1 つとして後発医薬品(後発品) が知られている，後発品は，先発医薬品（先発品） の特許期限が切れた後に市販される医薬品であり, 薬効成分，含量及び効能などが先発品のそれと同一 で販売され，先発品の代替が可能である. ${ }^{1)}$ さら に, この後発品は, 物理化学的性質を評価するため の規格試験, 安定性を評価するための加速試験及び 薬物動態を評価するための生物学的同等性試験を行 うことで製造販売承認の取得が得られ，先発品のよ うに臨床試験の実施は免除されている。このため先 発品と比較し, 後発品の製造承認販売に関する審査

近畿大学薬学部製剤学研究室

*e-mail: itoyoshi@phar.kindai.ac.jp
期間は短く，研究開発費も安価となり，後発品の薬 価は先発品に比べ格段に安く設定されている．この ような背景から，医療現場に対しては 2002 年以降 医療費の適正化を目的として, 処方箋様式の変更, 後発品を含む処方及び後発品の調剂や情報提供に対 する診療報酬上の評価導入などにより先発品医薬品 から後発品への代替の促進が行われている. しかし ながら，わが国における後発品普及率は，ほかの先 進国に比べ低いのが現状である。この要因として は，医薬分業の遅れ，一般名処方や代替調剤に対す る技能が確立されていないとともに，医療機関にお いて先発品から後発品へ代替を検討する際, 後発品 の効果や製剂自身の純度や品質に対する「疑念」が いまだ完全には取り除けていないのではないかと考 えられている. ${ }^{2-6)}$

これらの背景から, 後発品の普及にはこれまでよ り正確な製剂品質や純度の評価と先発品との生物学 的同等性をより明確にすることが重要と考えられ る。溶出試験は製剤間の品質を評価するために用い られる日本薬局方記載の試験法である. ${ }^{7)}$ また, 日 本の「後発医薬品の生物学的同等性試験ガイドライ 
ン」では，経口固形製剂に対して溶出試験の実施が 必要とされる場合の規定がある。ㄱ)それは，溶出挙 動が類似と評価されれば，生物学的同等性判定にお いて，ヒト追加試験が免除されるからである。この ため，後発品の純度を含んだ品質確認及び製剂評価 の検証を目的とした溶出試験法の改良又は試験工程 の簡略化は，後発品普及に向けて極めて重要と考え る．そこで本研究ではマイクロダイアリシス法の溶 出試験への応用について検討を行つた。 また，この 改良溶出試験法を用い先発医薬品と後発医薬品の製 鼡比較についても検討した。

\section{実 験 方 法}

\section{1. 先発品及び後発品の薬効成分及び斉形の選択}

マイクロダイアリシス導入法による溶出試験の検 討には，医療現場で汎用され，さらに後発品の種類 の多い $\mathrm{H}_{2}$-受容体拮抗薬シメチジンを用いた。この
剂形及び主薬含量は，対象後発品の中で最も多い $200 \mathrm{mg}$ 錠を選択した。本研究では，先発品を含め たこれらシメチジン錠計 3 種類 [先発品，タガメッ 卜 (Lot No. 1364C) ; 後発品 A, ストマチジン (Lot No. 8L12)；後発品 B，シメチパール（Lot No. 08403）] について検討を行つた.

2. 溶出試験法 溶出試験は，TOYAMA 社製 溶出試験器（NTR-1000）を用い，従来法による HPLC を用いた溶出試験［バッチサンプリング法, Fig. 1 (A) ] 7) 及びマイクロダイアリシス法による溶 出試験法 [マイクロダイアリシス導入法, Fig. 1 (B) ］の 2 種類について検討した。両方法とも，日 本薬局方の試験法に準じて行い，パドル法（50 回 転/分）を用い，試験液には水又は日本薬局方記載 溶出試験用 $\mathrm{pH} 1.2$ 及び $\mathrm{pH} 6.8$ 緩衝液を使用した。 バッチサンプリング法ではベッセル内溶液採取は医 薬品投入後 3 分間隔で行い，採取量は注射筒にて 1

\section{A Batch-sampling method}

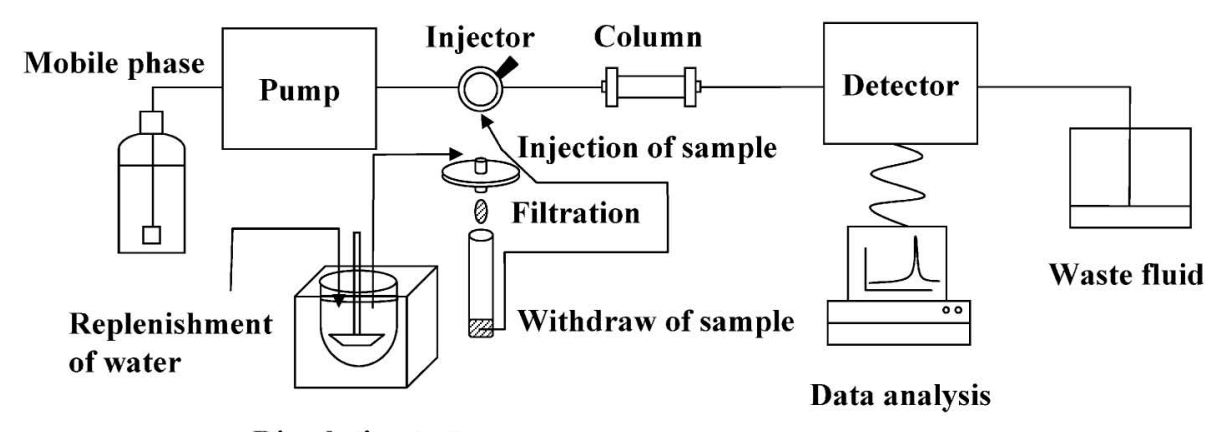

\section{B Microdialysis method}

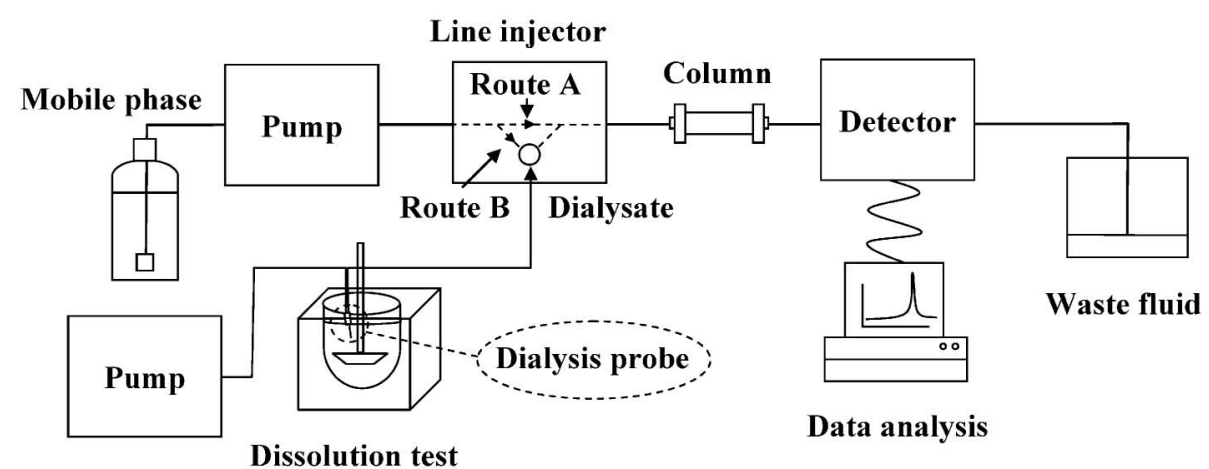

Fig. 1. Diagrams of Dissolution Test by Batch-sampling Method (A) and Microdialysis Method (B) 
回 $5 \mathrm{ml}$ で行った。また，採取分と同量・同温度の 試験液を補充した。試験液採取は，日本薬局方に従 い，試験液面とパドルの上端との中間で，容器壁か ら $10 \mathrm{~mm}$ 以上離れた位置から行った。この採取液 をフィルター (Minisart ${ }^{\circledR} \mathrm{CE}$, cellulose acetate, 0.45 $\mu \mathrm{m}$, Sartorius）にてろ過後 HPLC にてシメチジン 濃度を測定した。マイクロダイアリシス導入法によ る溶出試験法は，オートインジェクターEAS-20 （エイコム）に接続された再生セルロース膜製透析 プローブ（A-I-20-03，深さ $20 \mathrm{~mm}$ ，膜長 $3 \mathrm{~mm}$, プローブ部内径 $0.04 \mathrm{~mm}$ ，エイコム）を溶出試験 器内に挿入し，他方から ESP-32（エイコム）にて 水を送液（8 $\mu \mathrm{l} / \mathrm{min} ）$ することで，ラインインジェ クターへ試験液の注入を行い, HPLC 装置（JAS$\mathrm{CO}$ 社製，LC-Net II / ADC system, 送液ポンプ PU-2089Plus, 検出器 UV-2075Plus）にてシメチジ ンの測定を行った，HPLCによる測定は，ラグタ イム（1 分）を考慮し，透析プローブによるサンプ ル採取開始 1 分後の溶液を 0 分液として行った。測 定は 6 分間隔で行い，医薬品の主薬が完全に溶出す るまで行った。 HPLC によるシメチジン測定は以 下の条件にて行った。 カラムは, Inertsil ODS-3（3 $\mu \mathrm{m}, 2.1 \times 50 \mathrm{~mm}$ ，ジーエルサイエンス）を用い, 室温にて移動相 $\left(0.04 \mathrm{M} \mathrm{NaH}_{2} \mathrm{PO}_{4} /\right.$ アセトニトリル /メタノール/TFA : 345/20/35/0.7 by vol.) ${ }^{8)}$ で平衡 化した．移動相の流速は $0.25 \mathrm{ml} / \mathrm{min}$ とした。バッ チサンプリング法及びマイクロダイアリシス導入法 ともに HPLCへの注入試料量は $48 \mu \mathrm{l}$ として計算 し, 検出器 UV-2075Plus（JASCO）にて $242 \mathrm{~nm} の$ 紫外部吸収を測定した。また，先発品及び後発品か ら得られたデー夕は溶出試験開始前にシメチジン標 準品（Sigma 社製）及び HPLCにて作成したシメ チジン検量線から実濃度を算出した。本溶出試験で は $200 \mathrm{mg}$ のシメチジン錠を用い，試験液量は日本 薬局方に従って $900 \mathrm{ml}$ として行ったため, シメチ ジン錠中主薬が完全に溶解した際のシメチジン濃度 理論値は $222 \mu \mathrm{g} / \mathrm{ml}$ となる。したがって，本論文で はシメチジン濃度 $222 \mu \mathrm{g} / \mathrm{ml}$ を溶出率 $100 \%$ として 表した。実験は 6 回繰り返し，実験結果は平均值士 標準偏差（S.D.）で表した。また，標準偏差を用 いて溶出試験時における錠剤間の“ばらつき”を比 較検討した。

\section{結果}

1. マイクロダイアリシス法を用いた溶出試験の 透析プローブ固定位置の設定Ｆigure 2 には本実 験で試みた透析プローブの固定場所（A-D）を, Fig. 3 には Fig. 2 で示す A-D に透析プローブを固 定した際のシメチジン検量線を表す。A-Dいずれ の部位においても高い直線性が認められたものの, 透析プローブを透過するシメチジン量に差がみら れ，液面に近い $\mathrm{A}$ 及び $\mathrm{B}$ 点で液中の $\mathrm{C}, \mathrm{D}$ 点より 高值を示した. Figure 4 はパドルの回転数の異なる 条件下におけるシメチジン検量線について示す。透 析プローブは Fig. 2 の D 位置（日本薬局方溶出試 験試験液採取部位）に設置し測定を行った。パドル の回転数にかかわらず高い相関関係が認められた. 一方, 回転数の増加に従って, 透析プローブを透過 するシメチジン量の増加が認められた。このパドル 回転数（50 回転/分）の条件下におけるマイクロダ イアリシス導入法のシメチジン回収率は，試験液を HPLC へ直接注入した際の約 $1.6 \%$ であった（直接 注入法 $\mathrm{y}=318000 \mathrm{x}, \mathrm{R}=1.000, n=6)$.

2. pH 1.2 及び pH 6.8 試験液がマイクロダイア リシス法を用いた溶出試験へ与える影響Ｆigure 5 に日本薬局方記載 $\mathrm{pH} 1.2$ 及び $\mathrm{pH} 6.8$ 緩衝液を溶 出試験液として用い，マイクロダイアリシス導入法 によるシメチジンの検量線について示す。透析プ

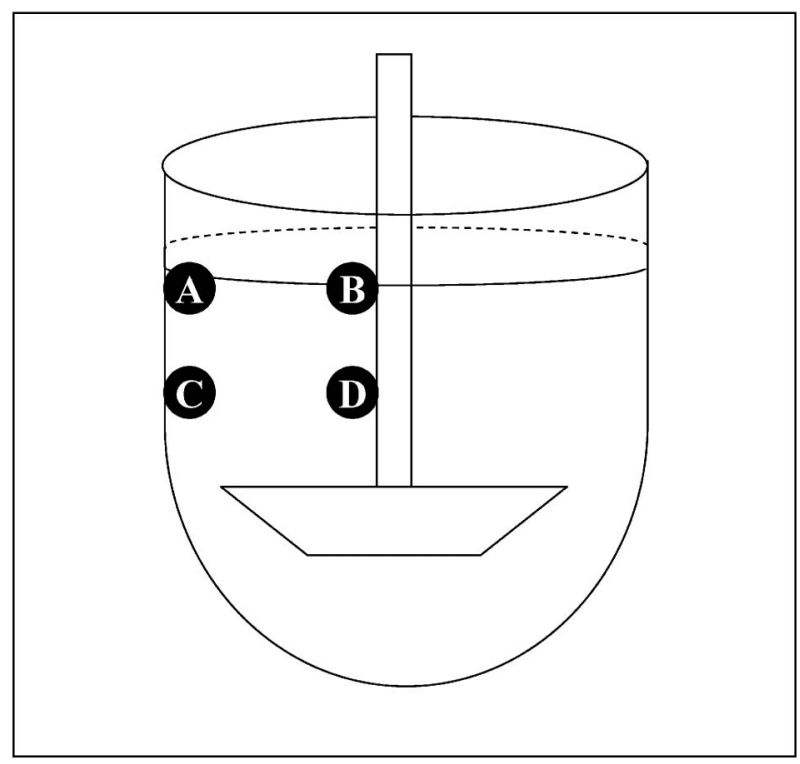

Fig. 2. Positions of Dialysis Probe in Microdialysis Method 

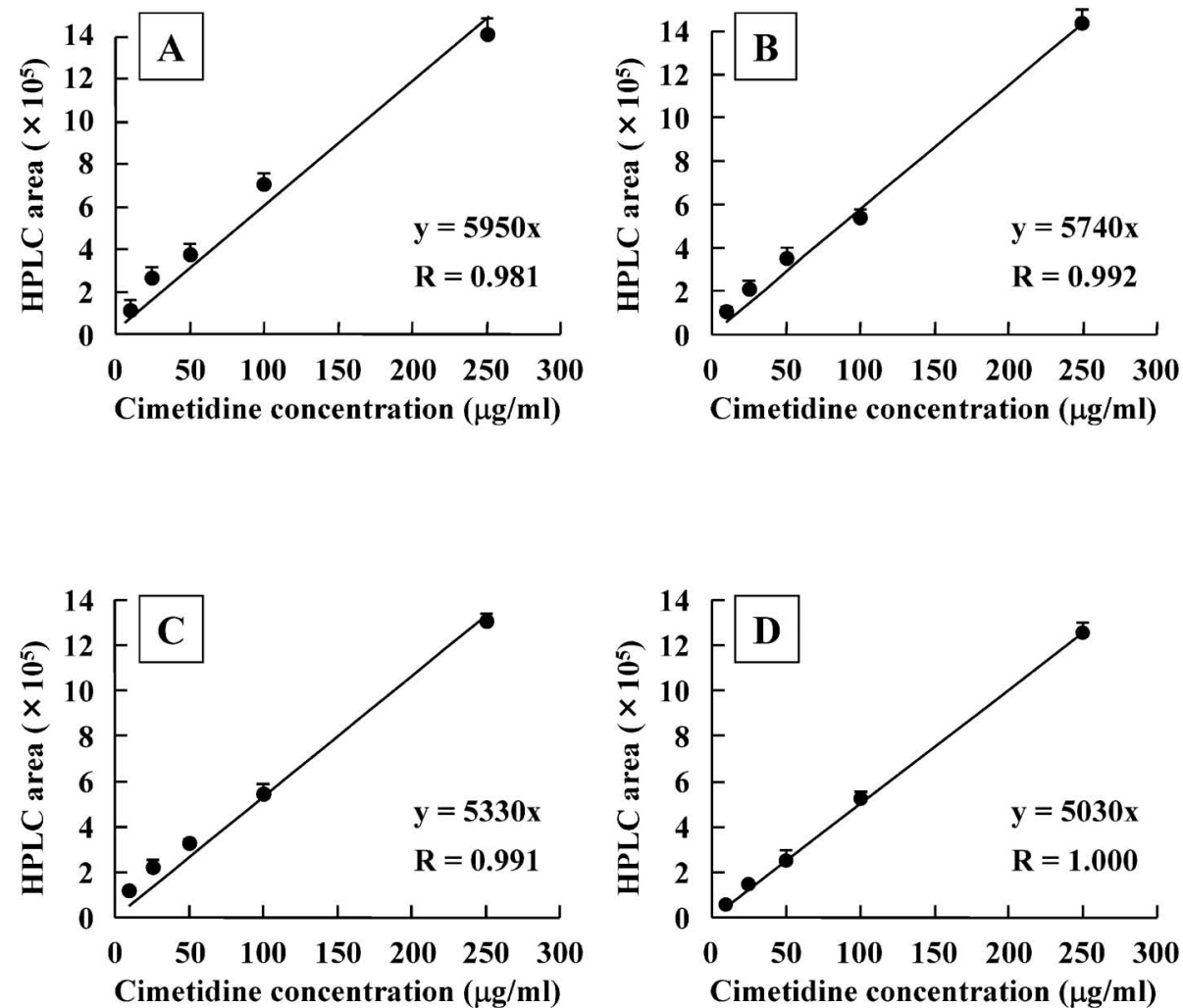

Fig. 3. Effect of Dialysis Probe Positions on Calibration Curves of Cimetidine by Microdialysis Method The dialysis probe was fixed in A-D shown in Fig. 2. The data are presented as means \pm S.D. of 6 experiments.

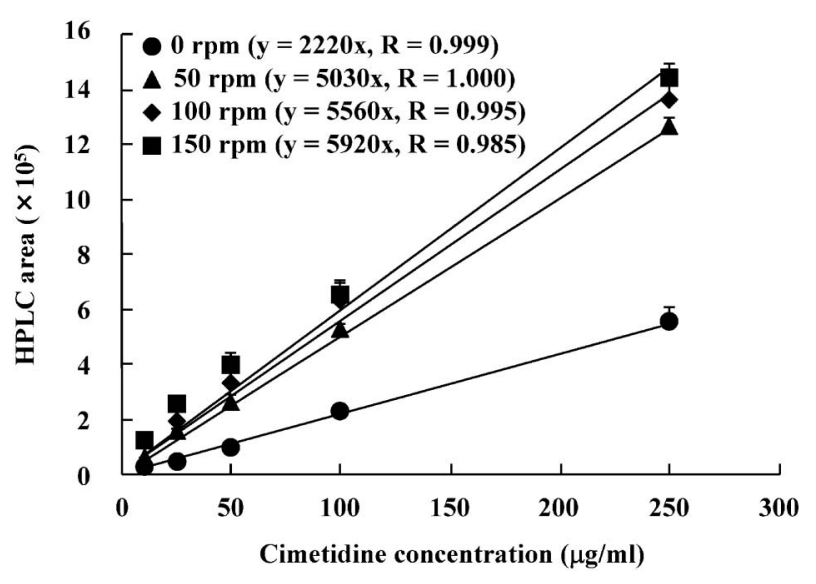

Fig. 4. Effect of Paddle Speed on Calibration Curves of Cimetidine by Microdialysis Method

The data are presented as means \pm S.D. of 6 experiments.

ローブは Fig. 2 の D 位置（日本薬局方溶出試験試 験液採取部位）に設置し測定を行った。 pH 1.2 及 び pH 6.8 溶液いずれにおいても濃度依存的な HPLC ピーク面積の上昇が認められ，さらにいず れの R 值も 0.99 以上と良好な值を示した。一方， シメチジンの透析プローブ透過量は，試験液に水を 用いた場合と比較し低值を示した（Figs. 4 and 5,
水 : $\mathrm{y}=5030 \mathrm{x} ; \mathrm{pH} 1.2: \mathrm{y}=3810 \mathrm{x} ; \mathrm{pH} 6.8: \mathrm{y}=$ $3600 \mathrm{x}, n=6)$.

3. マイクロダイアリシス法を用いた溶出試験に よる後発品シメチジンの品質評価 Figure 6 及び 7 にはバッチサンプリング法及びマイクロダイアリ シス導入法を用いたシメチジン錠先発品，後発品の 溶出曲線を示す。本実験で用いた 3 種のシメチジン 錠いずれにおいても，バッチサンプリング法及びマ イクロダイアリシス導入法間のシメチジン溶出挙動 に差は認められず，同等の溶出性を示した。一方 で，マイクロダイアリシス導入法ではバッチサンプ リング法の結果と比較し，溶出時間 9 及び 15 分の 溶出率の“ばらつき”（変動係数）は低值であった (Table 1)。先発品, 後発品間の比較では, 先発品 は実験開始から薬物溶出が認められ，開始 15 分で プラトーに達した。後発医薬品においても最終溶出 量は同様であり，先発品と差はみられなかったが, プラトーに達するまでの過程でその溶出速度に遅れ がみられ，試験開始後 9 分における溶出率は後発品 A では，先発品と比較し明らかな差がみられた (Fig. 7).しかし，「後発医薬品の生物学的同等性 

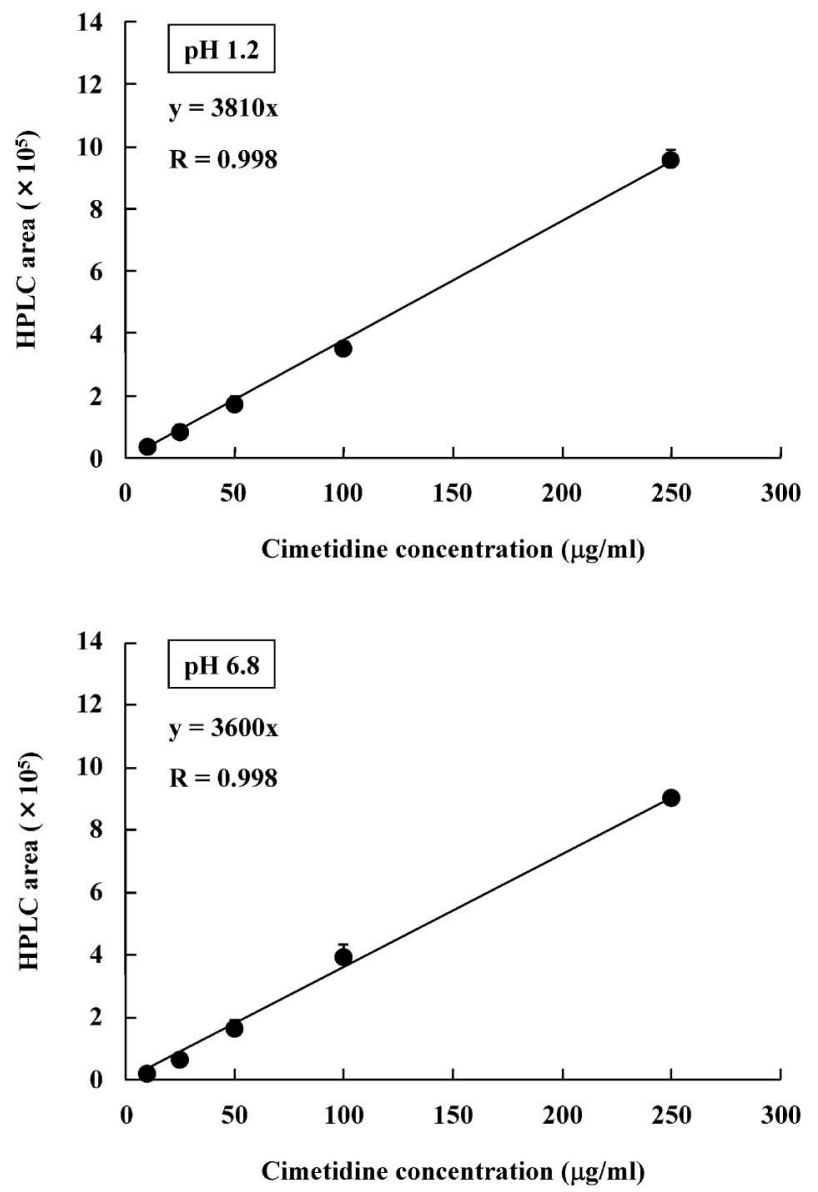

Fig. 5. The Calibration Curves of Cimetidine in $\mathrm{pH} 1.2$ and pH 6.8 Solution by Microdialysis Method

The data are presented as means \pm S.D. of 6 experiments.

試験ガイドライン」の基準から判定すると，今回試 験した後発品は先発品と同等性が認められた.

\section{考察}

溶出試験は日本薬局方に定められている試験法の 1 つで，錠剂やカプセルなどの内用固形製剤の品質 を一定水準に確保し，併せて製剤間の著しい生物学 的非同等性を防ぐことを目的として用いられてい る．近年の溶出試験法としては，ベッセル内溶液を ろ過後 HPLCによる定量法が用いられている [Fig. 1 (A) ].この方法は HPLCにより主薬の検出 を行うため, 複数の成分, 吸収のある賦形剂, 微量 成分がある場合に正確な定量及び純度確認が可能で ある。.また，短時間間隔（約 2 分間隔）での測定も 可能であり, 後発品を含んだ製剤の品質及び生物学 的同等性の検証に非常に有効な方法として用いられ ている。しかし，この試験法は一定間隔でベッセル 内から採取した溶液をろ過後 HPLC にて測定する

\section{Original product}
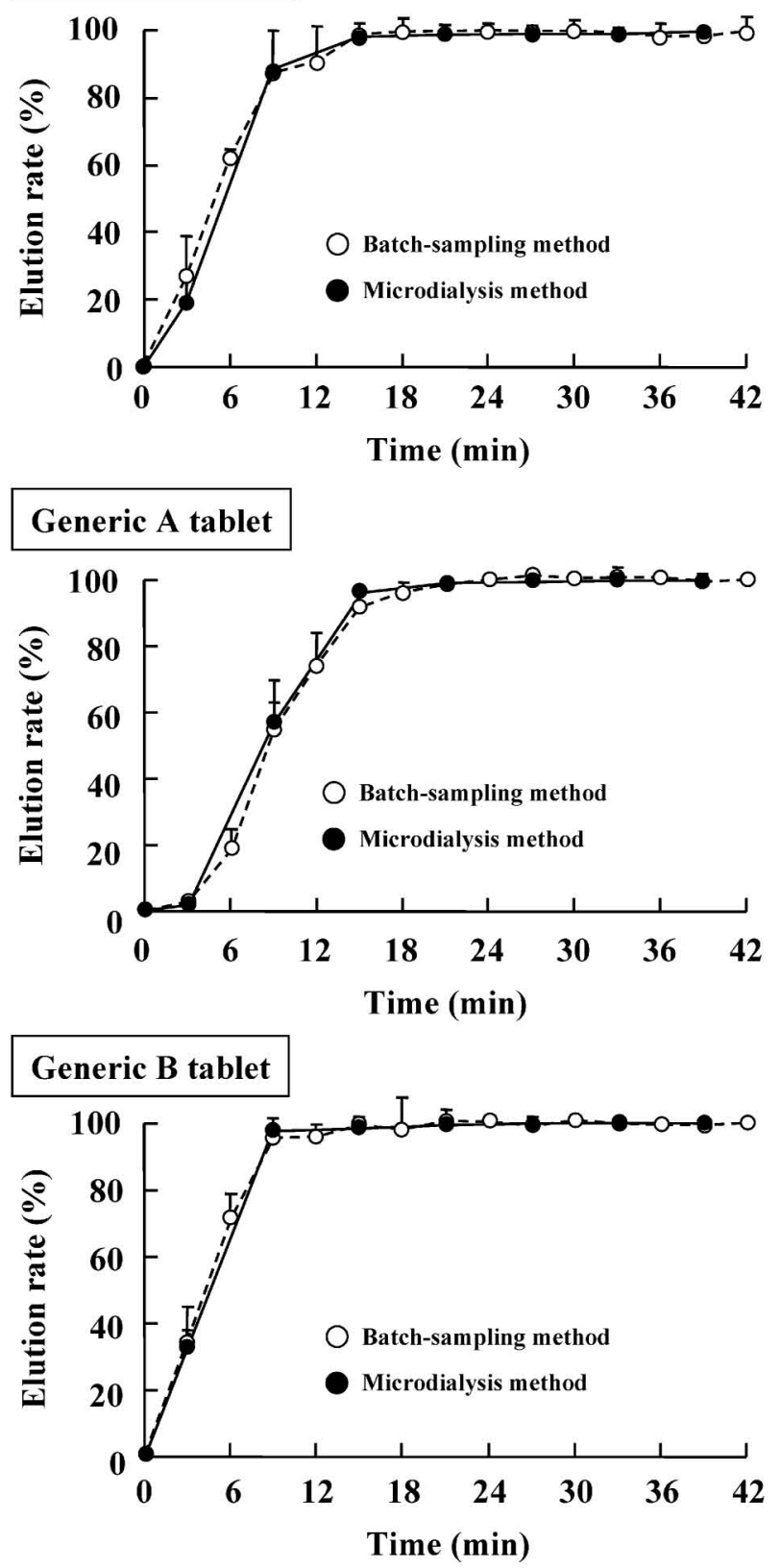

Fig. 6. Comparison of Dissolution Rate for Original and Generic Products of Cimetidine Tablet in Microdialysis Method

The data are presented as means \pm S.D. of 6 experiments.

ため，ベッセル内からの溶液採取及び補充や溶液の 濃度補正計算が必要である $[$ Fig. 1(A) ]。本研究で は，これらの工程を簡略化すべく，マイクロダイア リシス法を用いた溶出試験法開発を試みた。また, このマイクロダイアリシス導入法を用い先発医薬品 と後発医薬品の製剂比較についても検討した.

マイクロダイアリシス法は, 微小透析プローブ （直径 0.2-0.5 mm）の半透膜の性質を利用して，物 


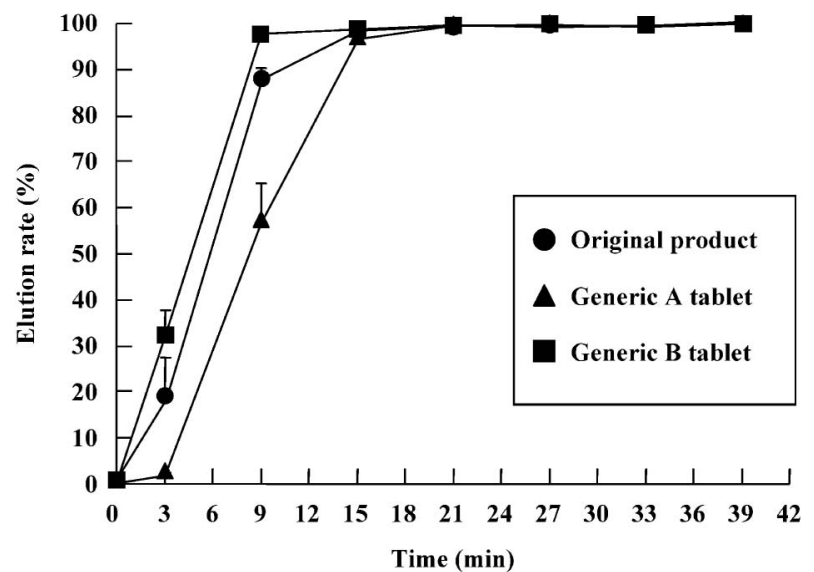

Fig. 7. Comparison of Batch-sampling and Microdialysis Methods Using Original and Generic Products of Cimetidine Tablet

The data are presented as means \pm S.D. of 6 experiments.

Table 1. Comparison of Mean Dissolution Ratio and S.D. for Dissolution Testes to Original and Generic Products between Batch-sampling and Microdialysis Methods

\begin{tabular}{lrrrrrr}
\hline \hline & \multicolumn{3}{c}{$\begin{array}{c}\text { Batch-sampling } \\
\text { method }\end{array}$} & & \multicolumn{2}{c}{$\begin{array}{c}\text { Microdialysis } \\
\text { method }\end{array}$} \\
\cline { 3 - 4 } \cline { 6 - 7 } & & Mean(\%) & S.D. & & Mean(\%) & S.D. \\
\hline Original product & $3 \mathrm{~min}$ & 25.1 & 13.2 & & 17.9 & 9.2 \\
& $9 \mathrm{~min}$ & 86.7 & 14.5 & & 87.7 & 2.7 \\
& $15 \mathrm{~min}$ & 100.6 & 3.6 & & 97.6 & 0.7 \\
Generic A tablet & $3 \mathrm{~min}$ & 3.5 & 1.1 & & 1.6 & 0.9 \\
& $9 \mathrm{~min}$ & 53.4 & 15.4 & & 56.2 & 8.7 \\
& $15 \mathrm{~min}$ & 90.9 & 4.5 & & 96.3 & 1.3 \\
Generic B tablet & $3 \mathrm{~min}$ & 36.0 & 11.2 & & 32.5 & 6.0 \\
& $9 \mathrm{~min}$ & 95.4 & 6.7 & & 97.9 & 1.6 \\
& $15 \mathrm{~min}$ & 100.0 & 2.2 & & 98.7 & 0.9 \\
\hline
\end{tabular}

The data are obtained from 6 experiments.

質を単純拡散により連続的に回収する方法である. この透析プローブは分子量 5000-25000 Da 以下の 物質を回収し，透析膜を介して得た試料はろ過や予 備精製なしで簢便に分析を行うことができる．この 透析膜には多くの種類が存在し, 低分子の物質の透 析には再生セルロース，セルロースアセテート，ポ リアクリロニトリル（神経ペプチド等の回収用）, ポリカーボネート等, 透析膜の種類によって大きさ や性質の異なつた分子を回収することが可能であ る. シメチジンは分子量 252.34 であるため, 本実 験では酸，塩基に対して安定であり，低分子の物質 用透析プローブとして再生セルロース膜を用いた。

本研究ではまずマイクロダイアリシス導入法を用
いた溶出試験を確立すべく，透析プローブによるシ メチジンの測定及び透析プローブの固定位置につい て検討を行った。 その結果, 透析プローブの固定位 置（Fig. 2) にかかわらずシメチジンの測定が可能 であったが，透析プローブ固定位置の違いにより透 析プローブを透過するシメチジン量に差が認められ た.さらに，これら透析プローブを透過するシメチ ジン量は，パドルの回転数増加とともに上昇した. これらの結果から, 流速の増加が透析プローブの透 過面における溶出薬物の一定供給を行うことによ り，シメチジンの透析プローブ透過量が増大するも のと考えられた。このため, マイクロダイアリシス 法の使用による溶出試験条件として，透析プローブ の固定及び設置場所が重要であることが明らかとな つた。本研究では, これらをふまえ日本薬局方記載 溶出試験の試験液採取部位（Fig. 2, D 位置）に透 析プローブを固定し以後の試験を行った.

一般的に溶出試験液には $\mathrm{pH} 1.2-\mathrm{pH} 6.8$ の緩衝液 又は水が用いられる。したがって，これら溶液にお いてマイクロダイアリシス導入法が利用可能かどう かを明らかとすべく, 溶出試験で用いられる $\mathrm{pH}$ 1.2 及び pH 6.8 溶液を用いシメチジン検量線作成 を試みた。 pH 1.2 及び pH 6.8 いずれの溶液におい ても濃度依存的な HPLC ピーク面積の上昇が認め られ，相関係数（R 值）も試験液に水を用いた条件 下と同程度の值を示した。 これらのことから, 再生 セルロース膜を用いた透析プローブにより，異なる $\mathrm{pH}$ 溶液においてもシメチジン回収が可能であるこ とが明らかとなった。一方，これらマイクロダイア リシス導入法の回収率は, 試験液を HPLCへ直接 注入した際の約 $1.6 \%$ と非常に低い回収率であった が，HPLC 法による分析には十分であった。この マイクロダイアリシス導入法の回収率を高めるため にはプローブ膜面積の拡大などが考えられる.

マイクロダイアリシス法が溶出試験に適用可能で あることが明らかとなつたため，ついで本法を用い 先発品及び後発品における溶出性の評価を行つた.

先発品及び後発医薬品は医療現場で汎用され，さら に後発品の種類の多い $\mathrm{H}_{2}$-受容体拮抗薬シメチジン 錠を用いた。マイクロダイアリシス導入法がバッチ サンプリング法と同等の溶出挙動を示すのかを確認 することを目的とした 3 分間隔と比較的短い間隔で 測定を行ったバッチサンプリング法とマイクロダイ 
アリシス導入法の比較実験（Fig. 6）では, 本研究 で用いた 3 種の医薬品製剤いずれにおいてもシメチ ジン溶出率が類似するという結果が得られた。この 結果は，マイクロダイアリシス法を用いた溶出試験 法は，医薬品の溶出性を正確に表すことを示した. さらに，同ロットの製剤及び検出器を用いたにもか かわらず，マイクロダイアリシス導入法ではバッチ サンプリング法の結果と比較し，溶出率の “ばらつ き”（S.D. 值）が少なかった（Table 1)。従来の溶 出試験法では，各時間毎に溶液を採取するのに対 し，本法では透析プローブにより連続的に溶液の採 取を行うため，従来法のような試験液採取工程が簡 略化されている，従来法と比較して，マイクロダイ アリシス法での “ばらつき”低下はこれら試験液採 取工程時に生じる “ばらつき”が簡略化により除か れたことに起因するものと示唆された。これらの結 果は，従来のバッチサンプリング法による溶出率の “ばらつき”は，製剤間の異なりだけでなく，試験 法自身の精度も影響していることを示唆し，本法 （マイクロダイアリシス導入法）が，医薬品の溶出 性をより明確に表すことが明らかとなった

先発品及び後発品の溶出挙動の比較では, 先発品 は実験開始から主薬の溶出が認められ，開始 15 分 でプラトーに達した。一方, 後発医薬品においても 最終溶出率は同様であり, 先発品との差はみられな かったが，プラトーに達するまでの過程でその溶出 率に差がみられ，試験開始後 9 分における溶出率は 後発品 $\mathrm{A}$ では, 先発品と比較し明らかな差がみら れた（Fig. 7)。先発品の試験 15 分時における溶出 率は約 $100 \%$ であり，「後発医薬品の生物学的同等 性試験ガイドライン」の溶出挙動の同等性の判定で は，標準製片が 15 分以内に平均 $85 \%$ 以上溶出する 場合，試験製剂が 15 分以内に平均 $85 \%$ 以上溶出す るか, 15 分における試験製剂の平均溶出率が標準 製剂の平均溶出率 $\pm 15 \%$ の範囲内にあることが示さ れている. 本研究では先発品及び後発品ともに, 15 分以内に平均 $85 \%$ 以上溶出しており, 今回の後発 品と先発品で同等性が認められた。

近年の後発品販売により，臨床では経時的な溶出 率が重要と考えられる徐放性製剤の先発品と後発品 の生物学的同等性が問題視されおり，後発品徐放性 製剂の詳細な試験が必要である。したがって，現在
筆者らは徐放化製剤 (ニフェジピン徐放錠)を用い， マイクロダイアリシス導入法を用いた溶出試験法が 徐放性製剂に対しても適用可能であるのかについて 検討しているところである。

以上，本研究では新規製剂評価法開発として，マ イクロダイアリシス導入法を用いた溶出試験法の確 立を行った。この方法は，近年のベッセル内溶液の ろ過を必要とする HPLCによる溶出試験法とは異 なり，マイクロダイアリシスに連結した HPLCを 用いることでろ過過程を連続的に行い，ほとんど溶 出液に濃度変化を与えず高感度かつ経時的な試験が 可能となった。 また, 従来の HPLC 法と比較し, より“ばらつき”の少ない測定が可能となつた．最 新の HPLC 法を用いた溶出試験は，全自動化が進 んでおり，本法のようなベッセル中溶液の採取及び 補充過程や溶液の濃度補正計算簡便化への改良は, より安価で精度の高い溶出試験を提供するととも に，今後多数販売される後発医薬品の品質管理にも 十分応用可能と考える.

\section{REFERENCES}

1) Ogata H., J. Pract. Pharm., 57, 15-23 (2006).

2) Kusumoto M., J. Pract. Pharm., 53, 27912804 (2002).

3) Honda T., J. Exp. Med., 210, 133-135 (2004).

4) Tokushima Y., Raku M., Kono E., Toyota K., Sogawa M., Takasugi M., Yakuji Shinpo, 2122, 1119-1123 (2000).

5) Nakamura Y., Fukuoka M., Kayano Y., Goto N., Wakiya Y., Masada M., Jpn. J. Pharm. Health Care Sci., 31, 158-163 (2005) .

6) Onoda M., Kanematsu M., Kitamaru T., Sakai T., Sakagami K., Tanaka K., Hamahata Y., Hirooka T., Fujii K., Matsuda M., Miki H., Mashimo H., Hada R., Arakawa Y., Yakugaku Zasshi, 127, 1159-1166 (2007) .

7) Division of Drugs, National Institute of Health Science, "Guidline for Bioequivalence Studies of Generic Products": 〈http://www. nihs.go.jp/drug/DrugDiv-J.html $\rangle$

8) Ho C., Huang H. M., Hsu S. Y., Shaw C. Y., Chang B. L., Drug Dev. Ind. Pharm., 25, 379385 (1999). 